\title{
Excretion of cadmium through bile and intestinal wall in rats
}

\author{
M. CIKRT and M. TICHÝ \\ Institute of Hygiene and Epidemiology, Department of Industrial Hygiene and \\ Occupational Diseases, Prague, Czechoslovakia
}

\begin{abstract}
Cikrt, M., and Tichý, M. (1974). British Journal of Industrial Medicine, 31, 134-139. Excretion of cadmium through bile and intestinal wall in rats. The excretion of $\mathrm{Cd}^{2+}$ through the bile and intestinal wall after intravenous administration of $\mathrm{CdCl}_{2}$ in non-toxic doses $(67,90$, and 120 $\mu \mathrm{g}$ of $\mathrm{Cd}^{2+}$ per rat) was studied in rats. The cumulative biliary excretion reached 24 hours after administration of the $67 \mu \mathrm{g}$ dose was $0.83 \%$, after $90 \mu \mathrm{g} 1.18 \%$, and after the $120 \mu \mathrm{g}$ dose $5.68 \%$ of the amount given. The highest excretion rate of $\mathrm{Cd}^{2+}$ was detected between 15 and 30 minutes after administration. There was no difference in the excretion through intestinal wall between the 67 and $120 \mu \mathrm{g}$ doses of $\mathrm{Cd}^{2+}$ per rat. The mean amount of cadmium found in the contents of the entire gastrointestinal tract and faeces was $5.5 \%$ of the administered dose. Using polyacrylamide gel disc electrophoresis it was found that $\mathrm{Cd}^{2+}$ is bound with at least two different components of the rat bile.
\end{abstract}

In the past two decades there has been an increase in industrial production and use of cadmium. Concomitantly, there has been an increased prevalence of both acute and chronic cases of clinically identifiable cadmium poisoning (Flick, Kraybill, and Dimitroff, 1971). Cadmium has been found not only deposited and accumulated in various body tissues but also in varying concentration throughout all environmental compartments (air, water, food, and soil).

For hitherto unknown reasons cadmium is excreted very slowly by both experimental animals and man and tends to accumulate in the body (Berlin and Ullberg, 1963; Lucis, Lynk, and Lucis, 1969). After subcutaneous or intravenous administration cadmium is concentrated predominantly in the kidneys, liver (Berlin and Ullberg, 1963; Lucis et al., 1969), pancreas, spleen, and intestine (Decker and Byerrum, 1956), and even in the endocrine glands (Berlin and Ullberg, 1963). During the 10 minutes after intravenous administration the content of cadmium in liver quickly increases whereas the content of the kidneys remains relatively constant in the same period (Perry et al., 1970).
Berlin and Ullberg (1963) studied the body distribution of cadmium in mice at various times after a single intravenous dose of ${ }^{109} \mathrm{CdCl}_{2}$, using the autoradiography method with sagittal whole-body sections. They found that cadmium left the blood very soon after injection and accumulated in the liver, kidneys, and mucous membranes of the intestinal tract. The concentration of cadmium in the organs did not change in course of the experiment but in the mucosa of the intestinal tract it decreased during the first 24 hours. According to these authors it seems likely that the mucosa of the intestinal tract, especially of the stomach and colon, took part in the excretion of cadmium. The autoradiograms strongly suggested excretion of cadmium in the bile.

According to Lucis et al. (1969) the principal route of cadmium excretion was via the gastrointestinal tract. These authors supposed that the appearance of cadmium in the lumen of the small intestine might be a result of biliary, pancreatic, and intestinal secretions. They believed that the colon might be involved in reabsorption of cadmium during the first 24 hours after injection.

In our study we followed the biliary excretion of 134 
cadmium and its excretion through the wall of the gastrointestinal tract after intravenous administration of $\mathrm{Cd}^{2+}$ to rats. Using polyacrylamide gel disc electrophoresis we compared the protein spectrum of rat bile with the location of ${ }^{115 \mathrm{~m}} \mathrm{Cd}$ on the electrophoreogram.

\section{Material and methods}

Female Wistar rats, mean weight $200 \mathrm{~g}(180-220 \mathrm{~g})$ and fed on a pellet diet, were used in the experiments. Rats were starved for 24 hours before the study but had free access to water.

The bile duct was cannulated with PE-10 tubing as described by Cikrt (1972). For separation of urine and faeces we used the modified method described by Östlund (1969).

Bile samples were taken at one-hour intervals and in some cases at two-hour intervals. The total duration of the experiment was 24 hours. The rats were given intravenously $\mathrm{CdCl}_{2}$ in doses of either $67 \mu \mathrm{g}, 90 \mu \mathrm{g}$ or 120 $\mu \mathrm{g}$ of $\mathrm{Cd}^{2+}$ per rat. In another series of experiments the rate of excretion of cadmium in the bile was followed for the first 80 minutes after administration. In these experiments bile was taken every 5 minutes. The rats were given ${ }^{115 m} \mathrm{CdCl}_{2}$ in doses of $95 \mu \mathrm{g}$ of $\mathrm{Cd}^{2+}$ per rat. The radioactivity of the administered isotope amounted to $10 \mu \mathrm{Ci}$ per rat.

After 24 hours (or 80 minutes respectively) the rats were decapitated, blood was collected and heparinized, and the liver, both kidneys, and the entire gastrointestinal tract were carefully removed from the abdominal cavity. Plasma was separated by centrifugation. The gastrointestinal tract was divided into six parts according to anatomical segments (Cikrt, 1972). The concentration of cadmium was determined both in the wall of the gastrointestinal tract and in the intestinal contents.

Cadmium concentration was determined with a Varian Techtron Atomic Absorption Spectrophotometer model AA-4 equipped with a $\mathrm{Cd}$ hollow cathode lamp. The analytical spectral line at $2290.5 \AA$ was used. The results were not corrected for light absorption of control bile samples.

The samples of bile and plasma were diluted with deionized water to $1 \mathrm{ml}$. Tissue samples, intestinal contents, faeces, and urine collected on filter paper were ashed by a wet method using nitric acid, and after removal of excess acid the residue was dissolved in $10 \mathrm{ml}$ of deionized water. In control samples of bile collected one hour before the injection of cadmium, absorption spectrophotometry with a Cd hollow cathode lamp was also carried out.

The measurement of radioactivity was carried out for ${ }^{115 m} \mathrm{Cd}$ in a well-type scintillation counter. Measurement time was selected after radioactivity sampling had demonstrated significant differences from the background. Counts were within a $\pm 5 \%$ error.

The number of rats in individual experiments varied from five to eight animals. The results are expressed in percentage of administered doses (means and 95\% confidence limits).

For plasma the results are expressed in terms of the entire plasma volume $(8 \cdot 3 \mathrm{ml}$ per $200 \mathrm{~g}$ rat (Spector, 1956)). The data in the tables for liver and kidneys are expressed as the percentage of the adninistered dose in relation to the entire liver or both kidneys.

The cadmium content in the wall and lumen of the individual anatomical segments of the gastrointestinal tract is given as a percentage of the administered dose. The content of cadmium in the faeces collected during 24 hours after dosing was added to that found in the colon lumen.

The bile was fractionated by the method of disc electrophoresis on polyacrylamide gel (Davis, 1964). The bile

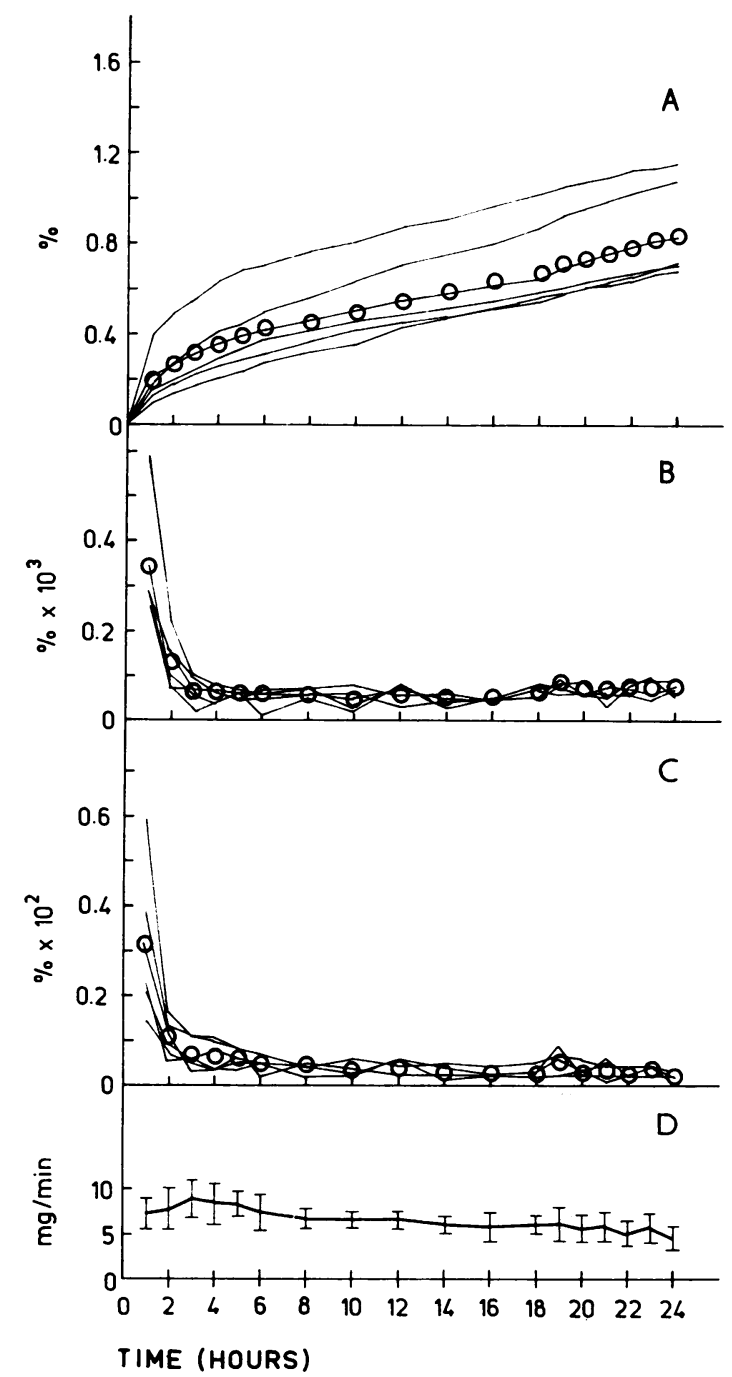

FIG. 1. Biliary excretion of $67 \mu \mathrm{g} \mathrm{CD}^{2+}$ per rat administered intravenously over 24 hours: (A) cumulative excretion as percentage of the administered dose; (B) percentage of excreted $\mathrm{Cd}^{2+}$ per milligramme of bile; (C) excretion of $\mathrm{Cd}^{2+}$ as percentage of the administered dose per minute; (D) bile flow in milligrammes per minute (mean $\pm 95 \%$ confidence limits of means). Solid linesresults from individual rats; open circles-mean values. 
collected from rats, after intravenous administration of $90 \mu \mathrm{g}$ of ${ }^{115 \mathrm{~m}} \mathrm{Cd}^{2+}$, was placed on polyacrylamide gel. After electrophoresis each gel was cut into twelve 5-mm slices which were then allowed to dissolve in $0.2 \mathrm{ml}$ of $30 \% \mathrm{H}_{2} \mathrm{O}_{2}$ for 12 hours at $60^{\circ} \mathrm{C} ; 6 \mathrm{ml}$ of scintillation solution, $3 \mathrm{ml}$ of absolute ethanol and $0.5 \mathrm{ml}$ of hyamine hydroxide were added to the dissolved samples which were then measured with a Tri-Carb Liquid Scintillation Spectrometer (Packard, model 3365). The cadmium con- tent of individual sections of electrophoreograms is given as the percentage of the total amount of radioactivity ${ }^{115 \mathrm{~m}} \mathrm{Cd}$ determined.

\section{Results}

The biliary excretion of cadmium in 24 hours is given as the mean and as the absolute values obtained

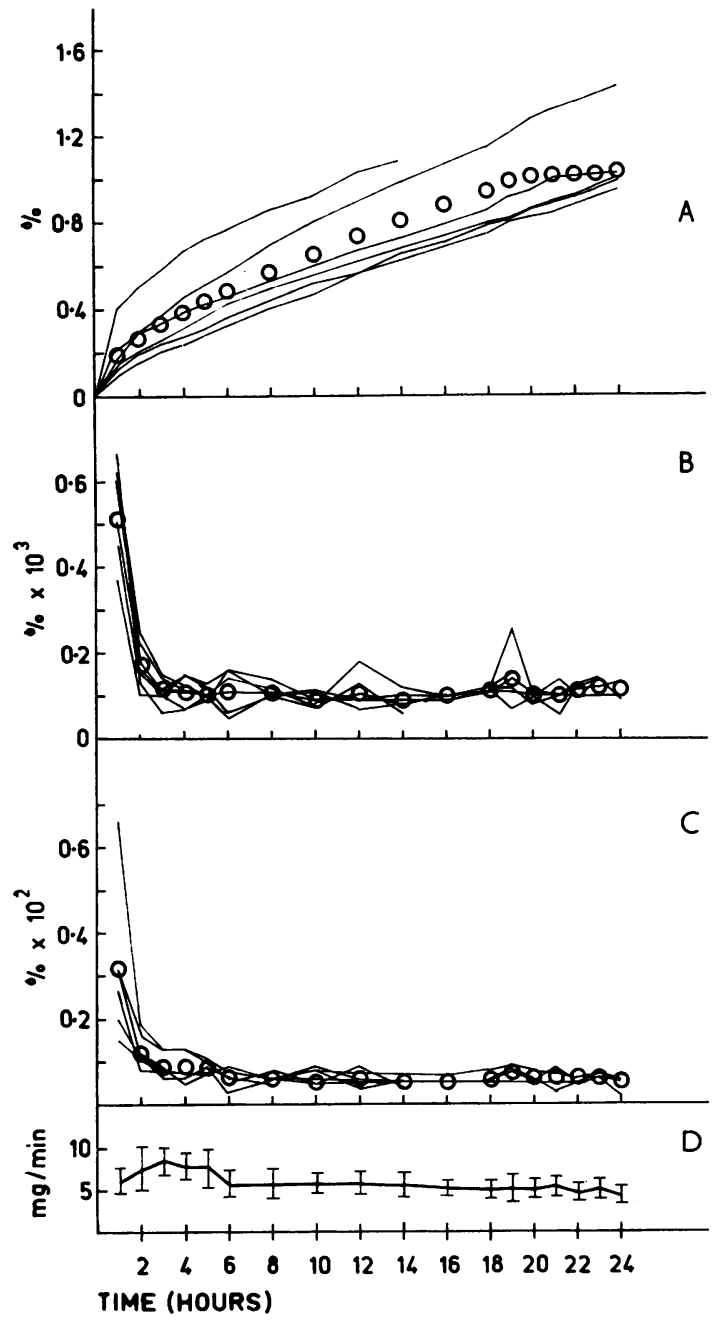

Fig. 2

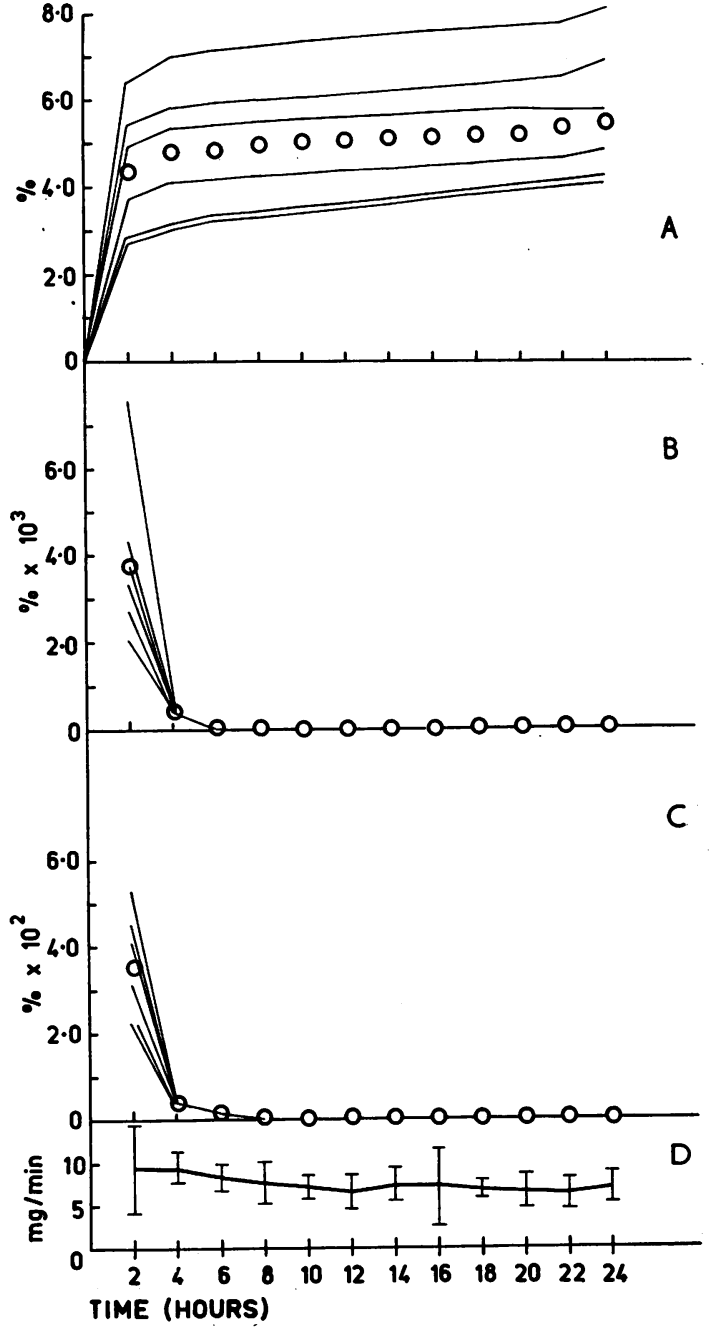

Fig. 3

FIG. 2. Biliary excretion of $90 \mu \mathrm{g} \mathrm{Cd}^{2+}$ per rat administered intravenously over 24 hours: (A) cumulative excretion as percentage of the administered dose; (B) percentage of excreted $\mathrm{Cd}^{2+}$ per milligramme of bile; (C) excretion of $\mathrm{Cd}^{2+}$ as percentage of the administered dose per minute; (D) bile flow in milligrammes per minute (means \pm 95\% confidence limits of means). Solid lines-results from individual rats; open circles-mean values.

FIG. 3. Biliary excretion of $120 \mu \mathrm{g}$ of $\mathrm{Cd}^{2+}$ per rat administered intravenously over 24 hours; (A) cumulative excretion as percentage of the administered dose; (B) percentage of excreted $\mathrm{Cd}^{2+}$ per milligramme of bile; (C) excretion of $\mathrm{Cd}^{2+}$ as percentage of the administered dose per minute; (D) bile flow in milligrammes per minute (means $\pm 95 \%$ confidence limits of means). Solid line-results from individual rats; open circles-mean values. 
from individual rats (Figs. 1 to 3 ). We believe that this method of presentation better expresses the uniform character of excretion than statistical characteristics only. In Figs. 4 and 5, which show the results of

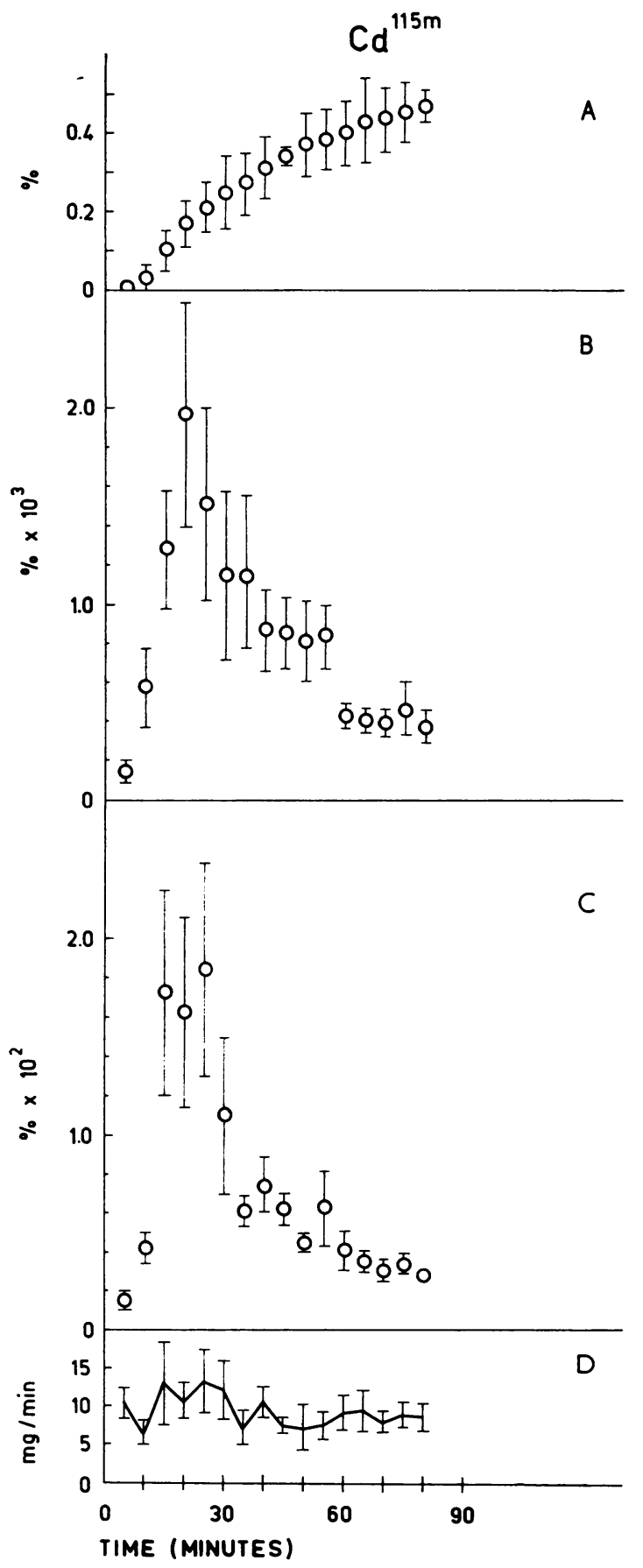

biliary excretion of ${ }^{115 \mathrm{~m}} \mathrm{Cd}$ within 80 minutes after dosing, only means and $95 \%$ confidence limits are shown.

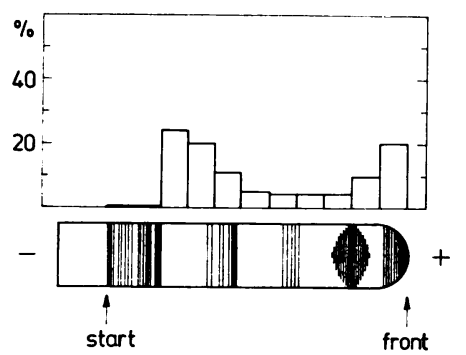

FIG. 5. Distribution of ${ }^{115 m} \mathrm{Cd}^{2+}$ detected on electrophoreogram of rat bile after intravenous administration

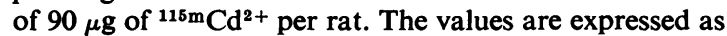
the percentage of the total amount of radioactivity determined on the electrophoreogram. Each column in the diagram represents the mean of six individual determinations.

Biliary excretion of cadmium

In the 24 hours experiments the following amounts of cadmium were excreted in the bile:

\begin{tabular}{c|c}
\hline $\begin{array}{c}\text { Administered dose } \\
\left(\mu g C d^{2+} \text { per rat }\right)\end{array}$ & $\begin{array}{c}\text { Biliary excretion } / 24 \mathrm{hr} \\
(\% \text { of administered dose })\end{array}$ \\
\hline 67 & $0.83 \pm 0.18$ \\
90 & $1.18 \pm 0.36$ \\
120 & $5.68 \pm 186$ \\
\hline
\end{tabular}

The curves B and C of Figs. 1, 2, and 3 show that the greatest part of cadmium is excreted in the bile within the first hour after its administration. In order to determine the position of the maximum rate of excretion we followed up the biliary excretion of ${ }^{115 m} \mathrm{Cd}$ for 80 minutes after dosing (Fig. 4). The highest excretion rate of ${ }^{115 \mathrm{~m} C d}$ was detected between 15 and 30 minutes after administration (Fig. 4B and C).

FIG. 4. Biliary excretion of $95 \mu \mathrm{g}$ of ${ }^{115} \mathrm{~m}^{2+}$ per rat administered intravenously over the first 80 minutes after dosing: (A) cumulative excretion as percentage of the administered dose; (B) percentage of excreted ${ }^{115} \mathrm{Cd}^{2+}$ per milligramme of bile; (C) excretion of ${ }^{115} \mathrm{mCd}^{2+}$ as percentage of the administered dose per minute; (D) bile flow in milligrammes per minute. Open circles-mean values (7 rats measured); vertical lines$95 \%$ confidence limits of means. 
Excretion of cadmium via wall of gastrointestinal tract Table 1 shows the cadmium content as the percentage of the administered doses for the entire alimentary tract found in the lumen of the individual segments 24 hours after administration. In the table the results of the experiment in which $90 \mu \mathrm{g}$ of $\mathrm{Cd}^{2+}$ were administered are not presented.

It will be seen that the largest amount of metal was found in the lumen of the caecum and colon including faeces. The total amount of themetal excreted within 24 hours via the wall of the gastrointestinal tract did not differ in the two doses of $\mathrm{Cd}^{2+}$ given.

TABLE 1

CADMium Content in Lumen of Gastrointestinal Tract 24 Hours AFTER AdMINISTRATION

\begin{tabular}{l|cc}
\hline \multirow{2}{*}{} & \multicolumn{2}{|c}{ Dose $(\mu \mathrm{g}$ per rat $)$} \\
\cline { 2 - 3 } & 67 & 120 \\
\hline Stomach & $0.34 \pm 0.15$ & $0.22 \pm 0.11$ \\
Duodenum & $0.19 \pm 0.08$ & $0.30 \pm 0.07$ \\
Jejunum & $0.26 \pm 0.10$ & $0.56 \pm 0.37$ \\
Ileum & $0.36 \pm 0.04$ & $0.41 \pm 0.25$ \\
Caecum & $2.63 \pm 0.50$ & $2.51 \pm 0.81$ \\
Colon + faeces & $1.52 \pm 0.34$ & $1.68 \pm 0.25$ \\
Entire gastrointestinal & & \\
tract + faeces & $5.31 \pm 1.21$ & $5.68 \pm 1.86$ \\
\hline
\end{tabular}

The values given in the table are means and $95 \%$ confidence limits of means. Values are expressed as a percentage of the administered dose.

Content of cadmium in liver, kidneys, urine, plasma, and wall of gastrointestinal tract

Table 2 shows the $\mathrm{Cd}^{2+}$ content in liver, kidneys, urine, and plasma 24 hours after dosing. It is apparent that there are no significant differences in the cadmium content of various tissues after different $\mathrm{Cd}^{2+}$ doses.

\section{TABLE 2}

Cadmium Content in Liver, Kidneys, Plasma, and Urine 24 Hours after Administration

\begin{tabular}{l|c|c|c|c}
\hline $\begin{array}{c}\text { Dose } \\
(\mu \mathrm{g} \text { per rat })\end{array}$ & Liver & Kidneys & $\begin{array}{c}\text { Plasma } \\
(8 \cdot 3 \mathrm{ml})\end{array}$ & $\begin{array}{c}\text { Urine } \\
(\text { per } 24 \mathrm{hr})\end{array}$ \\
\hline 67 & $79 \cdot 1 \pm 3 \cdot 1$ & $2 \cdot 3 \pm 0 \cdot 2$ & $0.51 \pm 0.06$ & $1 \cdot 7 \pm 0.9$ \\
90 & $76 \cdot 3 \pm 3 \cdot 4$ & $2 \cdot 7 \pm 0 \cdot 2$ & $*$ & $0 \cdot 9 \pm 0 \cdot 1$ \\
120 & $67 \cdot 3 \pm 8 \cdot 5$ & $1 \cdot 9 \pm 0.5$ & $0 \cdot 25 \pm 0.02$ & $0 \cdot 52 \pm 0 \cdot 14$ \\
\hline
\end{tabular}

*Not analysed

Values are expressed as a percentage of the administered dose (means and $95 \%$ confidence limits of means).
Table 3 shows the cadmium content in the wall of the individual anatomical segments of the gastrointestinal tract 24 hours after administration.

\section{TABLE 3}

Cadmium Content in Wall of Gastrointestinal Tract 24 Hours after Administration

\begin{tabular}{l|cc}
\hline & \multicolumn{2}{|c}{ Dose $(\mu \mathrm{g}$ per rat $)$} \\
\cline { 2 - 3 } & 67 & 120 \\
\hline Stomach & $0.74 \pm 0.16$ & $0.60 \pm 0.12$ \\
Duodenum & $1.18 \pm 0.43$ & $0.85 \pm 0.14$ \\
Jejunum & $1.52 \pm 0.70$ & $1.01 \pm 0.22$ \\
Ileum & $1.44 \pm 0.35$ & $0.96 \pm 0.20$ \\
Caecum & $0.62 \pm 0.10$ & $0.49 \pm 0.05$ \\
Colon & $1.54 \pm 0.68$ & $0.88 \pm 0.18$ \\
Entire gastrointestinal & & \\
tract & $7.04 \pm 2.42$ & $4.79 \pm 0.91$ \\
\hline
\end{tabular}

Values are expressed as a percentage of the administered dose (means and $95 \%$ confidence limits of means).

In the experiments involving administration of 95 $\mu \mathrm{g}$ of ${ }^{115 \mathrm{~m}} \mathrm{Cd}^{2+}$ per rat we found, 80 minutes after dosing, in the liver $72.2 \pm 0.3 \%$, in both kidneys $1.84 \pm 0.03 \%$, and in the plasma $3.59 \pm 0.25 \%$ of the administered dose.

The results for bile, kidneys, and liver obtained by atomic absorption spectrophotometry were compared with the data obtained using radioisotope ${ }^{115} \mathrm{Cd}$. No significant differences were observed. Moreover, the cadmium content in the intestinal lumen and faeces after the first 24 hours was no higher in our experiment than the values found by Decker et al. (1957). These authors used ${ }^{115} \mathrm{Cd}$ and similar experimental conditions. The differences are within the usual range of biological variation.

Fractionation of bile by disc electrophoresis on polyacrylamide gel

The protein electrophoretic spectrum of the bile of rats given ${ }^{115 \mathrm{~m}} \mathrm{CdCl}_{2}$ intravenously did not differ from the protein electrophoretic spectrum of the control bile taken from the same animals before administration of the radioisotope. The distribution of radioactivity of the protein electrophoretic spectrum of this bile is shown in Figure 5. $\mathrm{Cd}^{2+}$ cationsare concentrated in two parts of the electrophoreogram -in the pigment zone, and between the prestacking gel and the midzone (Englert, Wales, and Straight, 1970). Between both maxima, a part containing a smaller amount of cadmium was found.

\section{Discussion}

The biliary excretion of cadmium in the 24 hours after administration is very low. After the dose of 120 
$\mu \mathrm{g} \mathrm{Cd}^{2+}$ per rat we observed a higher biliary excretion of cadmium than after administration of 67 $\mu \mathrm{g}$ or $90 \mu \mathrm{g} \mathrm{Cd} \mathrm{Cd}^{2+}$ per rat. The highest biliary excretion of cadmium per minute is reached between 15 and 30 minutes after dosing.

Berlin and Ullberg (1963) and Lucis et al. (1969) observed that there was a possibility that cadmium was excreted in the bile. In our experiments less cadmium is excreted in the bile than via the wall of the gastrointestinal tract. Berlin and Ullberg (1963) suppose that cadmium is excreted into the faeces, particularly by the gastric mucosa and the mucosa of the colon, within the first 24 hours after administration. Lucis et al. (1969), however, emphasize the importance of the excretion of cadmium into the small intestine with subsequent possible reabsorption in the colon. In our experiments we found a relatively higher content of cadmium in the wall of the entire gastrointestinal tract by comparison with several other metals (Cikrt, 1972). The largest amount of cadmium in the intestinal content was found in the caecum and colon, including the faeces. The transit time of the intestinal contents is relatively rapid in the duodenum and upper jejunum and is reduced in the distal parts of the gut (Marcus and Lengemann, 1962). In the caecum the food remains for a long period; thus it may be presumed that the high content of cadmium found in the lumen of the caecum is due to the accumulation of the metal excreted in the upper segments of the digestive tract. Our results support the view that the colon might also play an important part in cadmium excretion. This observation would be in conformity with the autoradiographical findings of Berlin and Ullberg (1963). Our results are in good agreement with the data of Decker, Byerrum, and Hoppert (1957), who found $7 \cdot 3 \%$ of cadmium in the faeces 24 hours after the administration of a single intravenous dose of ${ }^{115} \mathrm{Cd}(0.63 \mathrm{mg}$ per $\mathrm{kg}$ ) to rats.

We have shown by electrophoretic fractionation of bile that cadmium is bound with at least two different components of bile. Part of the cadmium is accumulated in the pigment zone and another part in the region between the prestacking gel and midzone. Both parts are of practically equal size. Examination of bile by a chromatographic fractionation method using a Sephadex G-100 column (Havrdová, Cikrt, and Tichý, to be published) gave similar results. Part of the cadmium was bound to low molecular weight components and part to high molecular weight components of the bile. It is not certain whether the low molecular weight component is identical with metallothionein. It is known, however, that the formation of metallothionein in the liver is induced after administration of cadmium (Piscator, 1964). Because of the significant porosity of the hepatobiliary system (Schanker and Hogben, 1961) it is possible that transport of cadmium bound to metallothionein into bile takes place.

\section{References}

Berlin, M. and Ullberg, S. (1963). The fate of $\mathrm{Cd}^{109}$ in the mouse. An autoradiographic study after a single intravenous injection of $\mathrm{Cd}^{109} \mathrm{Cl}_{2}$. Archives of Environmental Health, 7, 686-693.

Cikrt, M. (1972). Biliary excretion of ${ }^{203} \mathrm{Hg},{ }^{64} \mathrm{Cu},{ }^{52} \mathrm{Mn}$, and ${ }^{210} \mathrm{~Pb}$ in the rat. British Journal of Industrial Medicine, 29, 74-80.

Davis, B. J. (1964). Disc electrophoresis. II. Method and application to human serum proteins. Annals of the New York Academy of Sciences, 121, 404.

Decker, C. F. and Byerrum, R. U. (1956). Distribution and retention of cadmium 115 in the albino rat. Federation Proceedings, 15, 240.

- Byerrum, R. U., and Hoppert, C. A. (1957). A study of the distribution and retention of cadmium-115 in the albino rat. Archives of Biochemistry, 66, 140.

Englert, E. Jr., Wales, E. E. Jr., and Straight, R. C. (1970). The proteins of human gallbladder bile with and without gallstones. Clinica Chimica Acta, 29, 319-331.

Flick, D. F., Kraybill, H. F., and Dimitroff, J. M. (1971). Toxic effects of cadmium: A review. Environmental Research, 4, 71-85.

Lucis, O. J., Lynk, M. E., and Lucis, R. (1969). Turnover of cadmium 109 in rats. Archives of Environmental Health, $18,307-310$.

Marcus, C. S. and Lengemann, F. W. (1962). Use of radioyttrium to study food movement in the small intestine of the rat. Journal of Nutrition, 76, 179-182.

Ostlund, K. (1969). Studies on the metabolism of methyl mercury and dimethyl mercury in mice. Acta Pharmacologica et Toxicologica, 27, Suppl. 1, p. 31.

Perry, H. M. Jr., Erlanger, M., Yunice, A., Schoepfle, E., and Perry, E. F. (1970). Hy pertension and tissue metal levels following intravenou: cadmium, mercury, and zinc. American Journal of Phy.riology, 219, 755-761.

Piscator, M. (1964). Cadmium in the kidneys of normal human beings and isolation of metallothionein from liver of rabbits exposed to cadmium. Nordisk Hygienisk Tidskrift, 45, 76-82.

Schanker, L. S. and Hogben, C. A. M. (1961). Biliary excretion of inulin, sucrose, and mannitol: analysis of bile formation. Americal Journal of Physiology, 200, 1087. 1093.

Spector, W. S. (1956). Body water and plasma volume. Mammals. In Handbook of Biological Data, p. 340 . Saunders, Philadelphia.

Received for publication 20 February 1973

Accepted for publication 6 November 1973 